\title{
Mothers and Breadwinners: Gender and Working Class Identity in Alsace, 1821-1936
}

\section{David Allen Harvey}

Louis Villermé, who toured the textile producing regions of France in 1835 and 1836 to study the "physical and moral condition" of the French working class, described the nineteenth century textile factory as "a sort of harem, in which all sexes and ages are mixed," and argued that the employment of women alongside men was one of the three principal abuses in the textile industry (the others were excessive hours and the use of loans and pay advances to bind workers to their employers). ${ }^{1}$ That Villermé should have focused so much attention on the mixing of the sexes in the workplace, rather than on any of the other problems and inequities of the early industrial system, is testimony not only to his lurid imagination, but also to the ways in which gender order, or patriarchy, and class order, or capitalism, were conflated in the minds of the nineteenth century bourgeoisie. The patriarchal family had long been portrayed as the bedrock of a properly ordered society, and its apparent breakdown among the emergent industrial working class seemed to many observers a sign of broader social decay. Gender roles were to be at the center of debates between employers, clergy, and the workers themselves over the causes of "the social question" and the proper means of resolving it. While, as we shall see, the workers of Alsace shared many of the assumptions of their social superiors regarding the proper roles of women and men, they used these common assumptions to reach radically different conclusions.

The economic upheavals produced by industrialisation in nineteenth century Europe brought with them unprecedented levels of popular protest and mobilization, provoking anxiety among the new bourgeois notables whose fortunes had been created by industry. France, the land of revolution, saw the uniquely precocious development of different varieties of socialism and frequent cycles of (usually unsuccessful) class insurrection, while Germany, where industrialisation came later and more quickly than in France, witnessed the rapid rise of the largest socialist party in Europe. ${ }^{2}$ Between the two lay Alsace, a province with a dynamic textile industry and developing metal and machine industries, where power resided among a handful of Protestant industrial dynasties perched precariously over a diverse and discontented working population. Shaken by the waves of revolution and class violence on both sides of the Rhine, the Alsatian patronat and the clergy of both the Protestant and Catholic faiths cast about for a means to stabilize social hierarchies and to return to the supposed deference and quiescence of preindustrial life. These representatives of rival Alsatian elites sought to solve the "social question" by attempting to preserve or restore the normative gender 


\section{Left History 7.2}

roles of the man as husband, father, and family breadwinner and the woman as wife and mother.

Numerous studies in recent years have examined the centrality of gender and family structure to nineteenth century responses to the "social question." Joan Wallach Scott's pioneering work not only made the case for gender as "a useful category of historical analysis," but also drew attention to the importance of l'ouvrière and to the gendered nature of nineteenth century discussions of industrial society. ${ }^{3}$ Class relations, like other relations of power, were often articulated in gendered terms, for as Rachel Fuchs has observed, "according to the reformers of nineteenth century France, the well-ordered state depended upon a well ordered family."4 Katherine Lynch and Elinor Accampo have also noted the centrality of normative concepts of gender, morality, and family relations to the reformers and philanthropists of nineteenth century France, and Susan Pedersen has argued that such attitudes, far from receding in the face of advancing industrialisation and state intervention, in fact formed much of the rationale for the formulation of French welfare and family policies in the twentieth century. ${ }^{5}$ While the gendering of class relations was perhaps especially pronounced in France, it was not, however, a uniquely French response to the dislocations of the early industrial era, for Kathleen Canning has noted that many German industrialists and reformers "sought to preserve the working class family as an anchor in a rapidly changing world, a bulwark against poverty, disorder, and decay." 6

While addressing many of the same issues as the studies mentioned above, this present article seeks to raise a number of new questions as well. The voices of nineteenth century workers, and especially of working women, are often difficult to recover, for as Mary Lynn Stewart has noted, "paternalists presumed they knew what was best for working women without asking them."7 This article, nonetheless, while not ignoring the ways in which normative gender roles were constructed and articulated from outside the working class, seeks primarily to examine the perceptions and responses of the workers themselves, as recorded in police reports and other official records from the departmental archives of the Haut-Rhin (Colmar) and Bas-Rhin (Strasbourg). This grassroots perspective will shed new light on how Alsatian workers reconciled their identities as men and women, husbands and wives, fathers and mothers, with the demands of their labour as industrial workers. While many, if not most, studies considering the interactions between gender and working class identities have focused primarily on the working woman, this study will examine how both femininity and masculinity were constructed and reconciled with the harsh realities of the nineteenth century labour market. Finally, while most studies of gender and class formation have examined a single national or local case (the comparative work of Pedersen on the welfare state cited above is a significant exception), this paper examines a border region which changed hands twice during the period examined here, and would change hands twice again 
thereafter. For that reason, it contributes to the broader study of both French and German, as well as autochthonous Alsatian, responses to the social question.

The growth of the textile industry in Alsace, especially in the department of the Haut-Rhin, was a destabilizing force in the traditional family organization of cloth production. Textile printing, a skilled trade practiced by well-paid male artisans, had first appeared in the Mulhouse area in 1746, and had stimulated the expansion of cottage spinning and weaving in the surrounding Vosges mountains, much of it done by peasant women in their homes. The mechanization of cotton spinning and weaving in the early nineteenth century moved this production from the home to the factory, and many women followed it there. Women workers were actively sought by textile entrepreneurs and certain tasks, such as beating raw cotton, weighing and packaging thread, bleaching woven cloth, retouching textile prints by hand, and eventually weaving on mechanical looms, became almost exclusively feminine occupations. These occupations were invariably among the lowest paid in textile establishments, however, and the higher paying, "skilled" tasks of spinning thread and printing cloth were generally reserved to men. ${ }^{8}$

The disparity in the wages paid to men and to women in the textile industry (in 1835 female workers earned from one to one and a half francs per day; while skilled male textile workers earned between two and a half and three francs ${ }^{9}$ ) were in part the result of a hierarchy of skills which was maintained both by employers and by male workers; few women were trained as spinners or textile printers. Behind this hierarchy of skill, however, lay the assumption that a man's wages were essential to the support of a family, while those of a woman were at best secondary. Joan Scott has observed that the leading classical economist of early nineteenth century France, Jean-Baptiste Say, factored into his wage calculations the economic cost of raising a family (socially necessary in order to ensure the continuity of the labour force) and attributed all of this additional cost to the adult male worker. Women workers, on the other hand, were generally assumed to belong to a household headed by a man, whether husband or father, and did not benefit from these calculations of a family wage. ${ }^{10}$

The lower wages paid to women, of course, provided powerful motivation for employers to hire them, especially as mechanization displaced artisanal spinners and weavers and created new categories of employment in their stead. Already in 1844, by which point mechanization had transformed all branches of the Alsatian textile industry, there were 16,178 women employed in textile production in the Haut-Rhin, and by the end of the century, that number had increased to 26,825 (employment of men in textile production increased much more slowly, from 23,930 to 25,237). ${ }^{11}$ As new and better paying jobs opened up for men in the growing heavy industrial sector, the textile industry in Alsace became increasingly "feminized," depending on a poorly paid predominantly female workforce for its labour power. 


\section{Left History 7.2}

Katherine Lynch has drawn a distinction between two broad discourses which related normative gender roles and notions of morality to the problems of poverty in early industrial France, whose advocates she identifies as "moral economists" and "social Catholics" (Rachel Fuchs uses the same categories, but further distinguishes between "moral" and "social economists"). ${ }^{12}$ Moral economists were middle class professionals, doctors, government inspectors, academics, and the like, who, according to Lynch, "represented a vanguard of bourgeois social thought and action designed to bring working class family behavior into line with the requirements of a new moral community they were attempting to construct." 13 While Fuchs distinguishes between "moral economists," who tended to blame workers' poverty on their immorality, and "social economists," who generally blamed the supposedly poor morality of workers on the hardships of poverty, both groups concurred that the adoption by workers of the middle class values of thrift, propriety, dedication to work, and patriarchal family relations, whether through industrial paternalism, self-help associations, or state intervention, was the only way to resolve the "social question." Social Catholics, whose spokesmen included both members of the clergy and committed laymen, called for voluntary charity, the re-evangelization of the workers, and the softening of the worst forms of capitalist exploitation to bring about class reconciliation. Generally less directly affiliated with the industrial patronat, Social Catholics were more willing to criticize employers as well as workers for failing to live up to Christian principles than were moral economists, although both groups were adamant in their defense of social hierarchies and property rights and their condemnation of social and moral disorder.

While both moral economists and social Catholics were present in Alsace, the province's unique religious composition and history of economic development presented an overall picture somewhat different from the rest of France. Alsace was, at the time of the French Revolution, home to about a third of French Protestants, predominantly German speaking Lutherans in the BasRhin to the north, and French-speaking Calvinists in the Haut-Rhin to the south. Although the Catholic population of the region still outnumbered its Protestants by more than two to one, the latter predominated among the industrialist caste, further separating it from the largely Catholic population which made its factories run. Alsace was one of the earliest and most dynamic of French industrial zones, and its industrial patriciate was united by bonds of family and sociability to a greater degree than elsewhere, with many "dynasties," such as the Dollfus, Koechlin, and Schlumberger families, wielding economic and political power for many generations. From the first stages of industrialisation, the Alsatian patrons developed a reputation for philanthropy and paternalism, symbolized by Jean-Jacques Bourcart's advocacy of restrictions on child labour, which prompted the French state to pass the child labour law of 1841, and by Jean Dollfus' leadership in the establishment of one of the first municipal 
housing projects in France, the Cité Ouvrière of Mulhouse. ${ }^{14}$ For these reasons, the "moral economist" position, empirical, pragmatic, and largely secular, held the reins of power more directly in Alsace than elsewhere, with both the power and the inclination to try to remake the workers in the image of the patronat, while the "social Catholic" (and, more rarely, "social Protestant") position was comparatively weaker, frequently criticizing the industrialists and lamenting the moral decay of the province, but often unable to do very much about either. While in the Stephanois enclave of Saint-Chamond, the Catholic Legitimist patrons studied by Elinor Accampo seem to have worked hand in glove with Catholic charities, funding the expansion of the local hospice and its charitable works, ${ }^{15}$ in Alsace, the Protestant industrialists and Catholic clergy seem often to have been at cross purposes, and to have pursued their social agendas with little interaction. Not only was social Catholicism not supported by the patrons, it also clashed with the conservatism of the church hierarchy in Alsace, and its leading exponent, the abbé Heinrich Cetty, was defeated in his 1893 bid for the Reichstag due in large part to the opposition of his ecclesiastical superiors. ${ }^{16}$

Although unable to affect the actions of industrialists, or influence state or municipal policy, social Catholics, sometimes joined by their Protestant counterparts, were the first to draw attention to the social dangers brought by the rapid industrialisation of Alsace. As early as 1821, the Alsatian clergy sounded the alarm that the growth of the textile industry, especially in and around the city of Mulhouse, brought with it the spectre of social and moral disintegration. An anonymous letter to the Director-General of the Mulhouse police blamed the textile factories for attracting a rootless proletariat from Baden and Switzerland as well as from the Alsatian countryside. The anonymous clergyman complained that "the mix of religions in these establishments, by destroying the principles which each worker might have conserved has produced absolute irreverence and the natural consequence of this confusion is the most scandalous immorality.... Especially in this city the foreign workers multiply and live in concubinage with girls from the local factories, hence the scandal, hence the masses of illegitimate children." 17 The letter concluded by demanding the expulsion of foreign workers, but the prefect of the Haut-Rhin, to whom it was forwarded, replied that this was impossible and recommended merely that local officials do what was possible to legitimize such relationships through marriage.

A generation later, the Protestant pastor L. Goguel of Sainte-Marie-auxMines sounded the same alarm on the disintegration of family life among the working class. While recognizing that "the wage question is predominant among all other industrial questions" and noting that poverty could lead workers to "despair, bitterness, prostitution, and misery," he denied that wages could be raised by administrative decree, as they remained tied to the fluctuations of the market. Instead, Goguel focused on the immorality of the working class as the cause of its misery and condemned workers for "an early tendency toward alcoholism and impurity, a pronounced love of luxury, a custom of reducing 


\section{Left History 7.2}

everything to profit, a feeling of apparent rather than true freedom from the demands of society and religion," arguing that as a result, "family life is ruined, and the seriousness of Christianity must always fight against tremendous lightness." Goguel especially condemned the mixing of the sexes in the workplace, arguing that "women too easily lose their manners and their virtue amid the unseemly clowning and jokes that their presence excites," and denounced concubinage as "an immense plague of our times." To address these problems, he recommended the intervention of "Christian women" from industrialist families to "establish the spirit of family amid the great industrial family of workers and masters." ${ }^{18}$ With regard to the dangers of working class immorality, if on nothing else, Catholic and Protestant Alsatian clergy spoke with a single voice.

Cohabitation without marriage does seem to have been relatively common among the workers of Mulhouse (in 1843, 16.5\% of children born in the city were born out of wedlock), ${ }^{19}$ and Villermé reported that the local population had even coined a German verb, paristeren, or "to do as in Paris," to describe it. He observed, however, that many individuals in this situation were foreigners who were prevented from marrying either because they lacked the necessary documents or because they would risk losing their citizenship in their countries of origin. ${ }^{20}$ Given the amount of notarized paperwork involved, the cost of formalizing a relationship could also be prohibitive, even for French-born workers; Rachel Fuchs has estimated that it could cost a couple up to a month's wages. ${ }^{21}$ Not all of these "Parisian marriages" were casual affairs, and some of them would eventually be formalized through legal marriage; Katherine Lynch has found that the number of marriages in the working class suburb of Dornach which involved the legitimation of children was over twice the French national average. ${ }^{22}$

Whether married or not, the quality of family life among the working class was also the subject of much debate and criticism in nineteenth century Alsace. Toward the end of the nineteenth century, the abbé Heinrich Cetty complained that for proletarian families, "unity exists only in the material fact of residing in the same house. The moral knot is absent." ${ }^{23}$ Cetty placed much of the blame for this state of affairs on the employment outside the home of women and children. Arguing that a woman's proper role was that of wife and mother, Cetty declared that factory work had "denatured and degraded" women, leading them into seduction or even prostitution. Moreover, young women who had worked long hours in the factories since early childhood had no examples to follow for their roles as wives and mothers, and Cetty lamented that many of them had no notions of cooking or housework. He suggested that working class women might better serve their families by remaining at home, where they could contribute to the family's economic position by working in the home or by cultivating a garden for the family's use. As for young men, Cetty argued that factory employment allowed them to become financially independent in their early 
teens, often tempting them to waste their earnings in drink, causing them to disrespect their fathers, and failing to teach them how to become responsible family providers in their own right. ${ }^{24}$ While there is certainly room to doubt the veracity of Cetty's assertions, he was far from alone in perceiving the decay of family ties in the working class as a pressing social problem in nineteenth century Alsace. Similar concerns had been voiced by Villermé a generation before, and, as we shall see, would be expressed from unexpected sources in the years that followed.

The numerous rural industrial establishments in nineteenth century Alsace seemed to offer a healthy counterweight to the moral decay which many observers believed they saw in Mulhouse. A contemporary observer noted that in Wesserling, a textile center in the southern Vosges, traditional moral values continued to govern workers' conduct, priests still wielded great influence over a deeply Catholic population, and concubinage was rejected as scandalous. ${ }^{25}$ Rural workers were thought not only to be morally superior to their urban counterparts, but also to be more complacent and less prone to conflict or protest on the job. The directors of Heilmann Frères in the village of Ribeauvillé informed the prefect of the Haut-Rhin in 1830 that they anticipated no problems from their rural workforce, "a hardworking class that wants only to be kept busy." 26 Similarly, the police commissioner of Cernay, an industrial town in the southern Vosges, reported in February 1865 that local textile workers, despite economic hard times, presented no danger to social stability because "the majority... are attached to their place of residence by family ties or by the possession of a few fields or a little house; therefore they have neither the tendencies nor the wishes of the workers concentrated in the great industrial centers."27

Apart from religious piety and extended family networks, land ownership was considered to be the most important factor in assuring the passivity of the rural workforce of Alsace. Marie-Madeleine Kahan-Rabecq has observed that land ownership "bred in (the workers) a certain peasant scepticism in the face of political or social changes," while their geographic dispersion impeded the development of class consciousness. ${ }^{28}$ German sociologist Heinrich Herkner noted a darker side to this condition, noting that land ownership made "free mobility out of the question," and that, unable to live from the products of their small fields alone, rural workers "had either to go to the factory and accept the wages offered there, to starve, or to emigrate." 29 The industrialist Alfred Goldenberg put the case for land ownership quite succinctly in an April 1890 letter to the German chancellor, stating that "A worker who is a property owner will never become a Social Democrat." 30 Throughout the nineteenth century, land ownership appeared to the patrons of Alsace as the best means for preserving both social and familial order among the working class.

The most notable example of an industrial establishment promoting land ownership among its employees was the De Dietrich metals and machine 


\section{Left History 7.2}

construction company, an establishment in the rural north of Alsace whose roots dated back to the seventeenth century. Most of the workers at the Dietrich forges and workshops came from peasant families in the surrounding countryside, and the firm took care to promote the ideal of the man as breadwinner and the woman as domestic caretaker. While the men of these families went to work at the forge, their wives, in the words of patron Albert de Dietrich, "cultivated the fields... cared for the cow, searched the woods for firewood and herbs." 31 Dietrich also noted that "it is to these results that we attribute the absence of strikes in our establishments." 32 This gendered division of labour gave the appearance of the continuation of the traditional patriarchal peasant family, but in reality, the unpaid agricultural labour of women enabled Dietrich to pay his male workers far less than was needed to support a family: in 1837 Dietrich paid his workers from 0.9 to 1.5 francs per day, whereas Villermé had determined the previous year that three francs a day, a salary obtained by textile printers and master artisans in a number of trades, was the minimum needed to sustain a family. ${ }^{33}$ While the Dietrich ironworks was exceptional in actively promoting land ownership among its workers, the widespread employment of "workerpeasants" was a distinct feature of the nineteenth century Alsatian industrial landscape, and, as we have already seen, was acclaimed by many small-town industrialists as one of the keys to social peace in the valleys of the Vosges.

Land ownership and farm labour often coexisted with seasonal industrial employment, particularly for women from working class families. Around fifty women and girls who were dismissed from the Boisgeol textile factory at Giromagny following an unsuccessful strike in July 1863 were told to work in the fields until the following winter, when they would be rehired. ${ }^{34}$ The suggestion reflects the common assumption in the nineteenth century that while men's work was essential, women's work remained merely auxiliary to the maintenance of the family. The seasonal employment of women was not unique to Alsace, for Jean Quaetert, observing similar employment patterns in upper Saxony, notes that "given the higher wages paid to men, it made good economic sense for the wives to take off time during the planting and harvesting seasons," but also concludes that "the choice meant, however, a more casual relationship to factory work... (which) justified employer practices of paying women less." 35 The same, as we have already noted, was true for Alsace as well.

The contrast between the apparent harmony of rural industrial society and the recurrent unrest of urban centers such as Mulhouse seemed to prove the moral economists' case that moral decay and sociopolitical subversion were linked, and led the Alsatian patronat to focus on moral improvement, and especially on the regeneration of the working class family, to bring social peace to the troubled cities of the province. A number of methods were introduced by industrialists to attempt to promote stable family life among urban workers. Several Mulhouse textile enterprises joined in 1866 to create the Association des femmes en couche to provide women workers with medical care and six weeks' 
paid maternity leave; like most other patronal social initiatives, it was financed by withholding from workers' paychecks. ${ }^{36}$ Employers sought to promote savings among the workers by creating company-run "mutual aid funds," which deposited a percentage withheld from workers' wages into a common fund upon which the workers could draw in time of need. ${ }^{37}$ Patrons sponsored a number of leisure associations, from singing societies to gymnastic clubs, intended to draw workers away from "the vulgar pleasures of the cabaret." 38

In 1868 the industrialists of Mulhouse, under the leadership of Jules Siegfried, established the "Cercle Ouvrier," a center for study and recreation for the use of the city's working class, dedicated, according to an official statement issued several years later, to "the social, material and moral well-being of the workers" as well as "the fusion and reconciliation of different classes of citizens." The center, which contained a reading room, billiards room, gymnasium, and lecture halls, organized regular concerts, plays, and lectures for the members (working class men) and their families. Intended as a means for the moral education of the workers, the center's directors denied charges that it contributed further to the destruction of the working class family, noting that it was frequented primarily by "young people who come to read, play music or exercise and who would probably spend their time much more poorly elsewhere." ${ }^{39}$ The abbé Heinrich Cetty, who organized the Cercle's Catholic rival, the Cercle de Saint-Joseph, made a similar argument, arguing that family life was already ruined among the working class and that the likely alternative to the Cercle was the cabaret. ${ }^{40}$

The charitable initiatives of Alsatian employers had certain limits and contradictions, however, and did not, in the long run, bring about the social peace which the patrons desired. Francis Hordern has criticized the "myopia" of the moral economists among the patronat, in whose eyes the misery of the working class was reduced to moral decay which could be remedied by moralizing solutions, "forgetting the low wages, long work hours, fatigue, and lack of resources, and thinking that the worker is poor because he wants to be." 41 As Hordern suggests, efforts to restore the working class family without improving its economic position were bound to fail. Furthermore, the vision of the patrons remained too narrow to recognize the presence and the needs of nontraditional families, such as single women and their children. The Colmarer Versorgungshaus was founded and financially supported by some of the leading industrialists of Alsace to house and care for the children of unwed mothers, whose grueling work schedule only allowed them to visit their infants on Sundays. ${ }^{42}$ Although far better than nothing, and preventing the desperate alternatives of child abandonment or infanticide that Fuchs has documented among poor Parisian women, this well-meaning but misguided initiative ignored the economic position of unwed mothers and, rather than giving them financial assistance and reduced work hours to allow them to care for their children, tended to destroy such families rather than to strengthen them. 
What were the effects of the moralizing efforts of the bourgeoisie and the clergy on the workers of nineteenth century Alsace? Traditional gender roles, casting the man as family provider and the woman as childbearer and caregiver, remained strong among the workers of Alsace, even when these normative roles bore little resemblance to the realities of working class life. As both Sonya Rose and Barbara Taylor have noted with regard to the English working class, these notions of man-as-breadwinner and woman-as-caregiver were not merely imposed on working people by middle class moralizers, but were derived by the workers themselves as they sought to make sense of their existence and defend their perceived interests, whether freely or within socially imposed constraints. ${ }^{43}$ Working men continued to judge themselves and one another on the basis of how well they fulfilled their family obligations and, as German SPD leader August Bebel insightfully observed, their failure to live up to the financial demands of their families was the principal cause that drove many workers to alcoholism. ${ }^{44}$ Working women, who Villermé and others recognized were responsible for maintaining the family budget, saw participation in collective social protest largely as an extension of the defense of their familial interests, creating what Temma Kaplan has described as "female consciousness." 45 Rather than guaranteeing their passivity and obedience, as bourgeois and clerical reformers had hoped, embracing the normative gender roles of mother and breadwinner allowed women and men, respectively, to press their economic and social demands more forcefully, in terms which employers and administrators found difficult to contradict.

Working class men in Alsace made frequent reference to their responsibilities as family breadwinners during wage disputes or in petitions made to local authorities demanding better conditions. Part of the reason for this practice was no doubt strategic, for Wally Seccombe has noted that, by making reference to the family wage, "working men could motivate their demands for higher pay in terms which the propertied classes found morally unassailable. They could say, in effect, 'If we were decently paid, our wives could remain at home and become good homemakers (just like your wives) and our children could stay at school and get a good education (just like your children)." 46 There was more to it than that, however, and adherence to normative bourgeois gender roles was not merely the product of acculturation and hegemony from above, but rather reflected the values and aspirations of many working men. In the preindustrial era, both peasant and artisan families worked and earned their living as a single unit, with all family members sharing in the duties of running a farm or producing a product at home. This premodern patriarchal domestic economy was thrown into question by the employment of women and children outside the home, and therefore outside of the control and protection of the family father. The separation of the spheres of home and work created an aspiration, almost never achieved among the working class, that a man's wages alone be enough to support his family. Joy Parr has written with regard to a 
German-Canadian artisan community that "men's credibility in the community was not grounded in their maleness per se, nor in their market allegiances alone, but rested as well in their demonstrated responsibility as family men" and that "husbands measured their personal worth as men by their ability to meet their household's needs for cash. They were particularly likely to compare themselves in this regard with their fathers, and their wives' place in the household with their mothers'."47 Male workers and artisans in Alsace, products of a similar culture, shared this system of values. Failure to live up to the normative expectations inherited from an agrarian or artisanal past threatened not merely a worker's place as head of his own household (although this concern was far from trivial), but his very identity as a husband, father, and man.

In the early months of 1850 , a group of cotton spinners in Kaysersberg saw their fortnight's pay reduced from an already low twenty-five francs, "too little to live on and too much to die on," to a miserable eighteen francs, at which point they refused to work and petitioned the prefect of the Haut-Rhin for assistance, pleading, "Consider, M. le Préfet, if a poor family father can obtain the basic necessities which the people have been lacking for so long with such a sum ... and you will see that the poorest, the unhappy workers and their families, suffer in terrible misery." ${ }^{48}$ The appeal failed to sway the prefect, who reminded the workers of the inexorable laws of supply and demand, and the petitioners were forced to accept the wage cuts and return to work. During another spinners' strike over wage reductions, this one in Thann in January 1858, a delegation of strikers petitioned the local police commissioner to intercede on their behalf, "claiming that it was impossible to support their families on such a trifling wage," but their appeal likewise failed to achieve a return to the previous wage scale. ${ }^{49}$ Two years later another group of spinners petitioned the Minister of Agriculture and Commerce over wage cuts of eight to nine francs on a previous salary of thirty francs per fortnight, arguing that "His Excellency will easily understand that it is a too considerable loss for these hardy workers who are all family fathers and live only from the profits of their labour." ${ }^{50}$ Such appeals multiplied during the 1860s, when the American Civil War cut off the supply of raw cotton to Europe, causing hard times for the Alsatian textile industry. The spinners of the Witz factory in Cernay went on strike in May 1863, complaining that the twenty-one francs they earned per fortnight was not enough to live on. The local police commissioner confirmed the wage rates and noted that "there are among them fathers of families with five, six, and even seven young children, their wives, and their sickly parents," with no other income to support themselves. ${ }^{51}$

Even when such appeals to family obligations met with a sympathetic ear from local officials, however, they were by no means guaranteed to succeed. In August 1846 the linen combers of Séléstat petitioned local authorities for protection against competition from immigrant workers, arguing that "nonFrench foreigners, and single men at that, have come to practice their profession 
near this town and outside of the wage scale, while licensed family fathers have nothing to do to be able to survive." 52 The mayor and subprefect of Séléstat supported their request for the repatriation of these foreign competitors, but their decisions were vetoed by the prefect of the Bas-Rhin, who noted that such an action would provoke reprisals against French workers abroad.

Much like their male counterparts who constantly referred to themselves as "family fathers," those women who became actively involved in collective protest in the workplace and the political arena presented themselves not only, sometimes not even primarily, as wage-workers, but rather as the mothers of needy children, whose well-being was at the root of their discontent. This was especially the case in the early nineteenth century, when textile firms employed large numbers of children as auxiliary workers and paid them pitifully low wages (Villermé stated that the upkeep of children in 1830s Alsace cost their families more than the half-franc they could earn for a full day's work). ${ }^{53}$ When the men, women, and children employed in the textile industry in the Vosges town of Bitschwiller went on strike in September 1835, the subprefect of Belfort harangued them for three hours on the need for them to return to work, but he later reported that "all was in vain, especially with regard to several women who were truly exasperated by the state of misery in which they were kept, due to the insufficient wages paid to their children for a long and exhausting day's work." 54 When the exploitation of child labourers, acknowledged as such by Villermé and by the industrialist and reformer Jean-Jacques Bourcart, was at stake, women's role as mothers- led them not into domestic passivity, but rather into angry protest.

The question of the "respectability" of the working class, and especially the virtue of working women, was also an issue for many Alsatian workers, for working women, especially single young women, were tarred by a stigma of immorality independent of their own actions or personal character. Joan Scott has observed that nineteenth century French observers used the same term femme isolée - to describe both working women and prostitutes, and comments that "the interchangeable usages of femmes isolées suggested that all such working women were potential prostitutes, inhabiting a marginal and unregulated world in which good order - social, economic, moral, political was subverted." 55 The term in question is also a revealing one; what observers such as Villermé and Cetty found threatening about working women was their "isolation," that is, their relative economic independence from patriarchal control. The cognitive leap from economic independence (often more apparent than real, as few women workers earned enough to support themselves completely) to sexual licentiousness does bear witness to the vulnerability of working women, especially single women, to sexual harassment from employers and managers, ${ }^{56}$ but more than anything else, it demonstrates that most bourgeois observers saw women primarily as sexual beings, and only secondarily as wage-earners. 
One incident from a mid-nineteenth century textile town in the Vosges clearly illustrates the dichotomy between clerical and working-class assumptions about the respectability of female factory workers. According to a police report from Kaysersberg, on 10 May, 1857, Joseph Rothenslug, the proprietor of a small vinyard who also worked as a factory guard, and his wife presented their infant son for baptism in their local parish church. The godparents who accompanied them in their observance of this ritual were both twenty-one year old factory workers, the locksmith Jean-Michel Wassermann and a female textile worker identified only by her surname of Kniebiehly. When they presented themselves in the church, the priest, abbe Caspar, refused to accept Kniebiehly as godmother, exclaiming loudly, "Do not let her approach the baptismal fount!" The young woman blushed and ran out of the church, while the godfather, Wassermann, demanded to know why his counterpart had been rejected. Abbé Caspar rebuked him for asking, and when pressed responded haughtily that he "did not have to give explanations to smelly factory workers." The aggrieved parties then appealed to the police, demanding redress for "the insult made against all of the corporation of workers." 57 The police report ends without revealing how this village drama played itself out, but the incident reveals that workers themselves had different assumptions about morality and respectability than did the bourgeois and clerical observers who denounced their supposed debasement. In this case, the priest's condemnation of Kniebiehly was almost certainly unfounded; had there been any merit to it, it is unlikely that her fellow workers, who almost certainly would have known her better than did the village curé, would have selected her as godmother for a baptism, or would have pressed her case once she had been insulted.

The annexation of Alsace to Germany following the Franco-Prussian War brought a number of significant changes to Alsace. The strict laissez-faire policies of the nineteenth century French state gave way to the more interventionist stance of the German Second Reich, and the German Gewerbeordnung (labour code) of 1869 , which authorized strikes and labour unions, was introduced in Alsace, albeit twenty years after it became effective in the rest of the Reich, while the introduction of German compulsory primary education laws proved a greater impediment to the use of child labour in Alsace than the weak 1841 French statute had ever been. The political monopoly which Alsatian industrialists had long enjoyed in Mulhouse, not to mention in the company towns of the Vosges, was challenged first by the agents of the German Beamtenstaat, and later by the organized labour movement. German capital investment in the region developed or expanded new industries, especially in metallurgy, machine construction, and mining, and further weakened the monopoly of the local patronat over economic affairs in the province. ${ }^{58} \mathrm{Amid}$ so much change, however, the normative roles of man as breadwinner and woman as nurturer proved remarkably stable, and were shared not only by German administrators, moral economists, and social Catholics, but, more surprisingly, by the German Social Democratic labour movement as well. 
The "family father" rhetoric of Alsatian working men survived the FrancoPrussian War and the transition to German rule in Alsace. In August 1889, the textile workers of Bischwiller petitioned Wilhelm II, who was visiting Alsace at the time, to grant them assistance, as a labour dispute which had left them idle dragged on with no end in sight. As "citizens and German imperial subjects," they begged him to take pity on "the poor workers' wives and children, who can be seen in the bitterest poverty.... How else can it be with an average wage of six to eight marks per week to feed an entire family?" 59 The petition failed to achieve its desired effect, however, and the workers of Alsace became increasingly aware that, if their economic position was to be improved, it would have to be through their own efforts and not through the benevolence of employers, clergymen, or kings.

The German Social Democratic labour movement, which gained a foothold in Alsace in the final years of the nineteenth century, was ridden with contradictions regarding the proper place of women. Party leader August Bebel, who devoted his best-known book to the "woman question," advocated the full emancipation of women within the socialist society which was to come, but also argued that "under existing conditions, the admission of women to all industrial occupations can have for its only effect that the competitive struggle of the working people become ever sharper, and rage ever more fiercely. Hence the inevitable result - the lowering of incomes for female and male labour." Capitalism, he declared, sought to maximize profits by replacing male workers with the "more docile and submissive, and less exacting woman."60

Bebel shared with Villermé and Cetty the assumption that a woman's primary role was that of wife and mother, and like them, he lamented that "with the extension of female labour, the family life of the working class goes ever more to pieces... and immorality, demoralization, degeneration, diseases of all nature and child mortality increase at a shocking pace." While Bebel advocated freeing women from "the narrow sphere of strictly domestic life to a full participation in the public life of the people," his advocacy of full political and civic rights for women was likewise tied to their domestic role. Bebel wrote that "a woman who gives birth to children renders, at least, the same service to the commonwealth as the man who defends his country and his hearth with his life," and argued that a politically aware woman would support her husband in his syndical obligations, rather than begrudge him the portion of his pay that went to union dues. ${ }^{61}$

Given the assumptions of SPD leaders such as Bebel regarding the proper role of working class women, it is not surprising that the relationship between working women and the party in Alsace was not always a smooth one. A May Day brochure from 1898 demanded women's suffrage, arguing that "woman is interested in indirect taxes and customs policies as a housewife, who must keep house with very limited means, as a worker in social and economic policy, as a mother in public education, and as bearer and first educator of future soldiers in 
military and foreign policy." 62 While recognizing women as citizens (although defining their citizenship primarily in terms of their biological and familial functions), many male unionists and party militants resisted seeing them as fellow wage-earners. A placard posted in Dornacher Strasse in Mulhouse in March 1896 to call the workers to struggle also appealed to women "not to allow yourselves to be imprisoned forever in the factories. Housekeeping is your paradise." ${ }^{63}$ With the notable exception of May Day festivals, women were rarely included in party and union assemblies, which frequently revolved around institutions of masculine sociability such as the cabarets, in which women generally were not welcome. ${ }^{64}$ Such expressions of "proletarian anti-feminism," Mary Nolan has noted, merely turned women away from the SPD and its organizations; only $8 \%$ of the members of party-affiliated unions throughout Germany and only $4 \%$ of party members in Alsace and Lorraine were women in the years immediately before the First World War. ${ }^{65}$

In the Alsatian textile industry, in which the majority of workers were women by the late nineteenth century, strikes often foundered on the lack of cooperation between male and female workers, as men resented their female colleagues as wage-cutting competitors and often failed to support their economic demands. This tension was already present in the years before the German annexation of Alsace; a March 1860 strike by 116 female mechanicalloom weavers at the Gros-Roman establishment in Saint-Amarin quickly collapsed when male workers did not join the women in the walkout ${ }^{66}$ The annexation and the introduction of German Social Democracy did not, at least at first, cause these attitudes to change. In July 1893, 100 women workers from the Heilmann Koechlin \& Kuneyl textile factory went on strike, protesting an increase in the pace of the machines at which they worked. The male spinners, the best paid workers of the enterprise, and their assistants did not support the strike, and management refused to meet with the female strikers, who soon had to return to work accepting the newly intensified rhythm of production. ${ }^{67}$ Male workers, who often resented competition from women, continued to see women's work as less important to family survival than their own, and often refused to interrupt their own employment to support women's demands.

The traumatic experience of the First World War brought important changes to the gender dynamics of factory life in Alsace and elsewhere in the German Kaiserreich. The mobilization of the majority of able-bodied adult men left many vacancies in industrial employment, which for lack of alternatives employers had to fill with female workers, despite continued beliefs that women, while well-suited to the textile industry, were incapable of performing more grueling physical tasks in heavy industry. ${ }^{68}$ The war years saw a decline in textile production as capital and resources were shifted to more urgent military production. In the department of the Bas-Rhin during the war, women made up $18 \%$ of the workforce in heavy industry, $32 \%$ in public works, and $32 \%$ in shipping, as opposed to less than $2 \%$ in all of these sectors prior to $1914 .^{69}$ 
Women's work, which before the war had often been portrayed (falsely) as peripheral, was now clearly central to the maintenance of working class families, as husbands and fathers remained absent and often fell as casualties of war. Female workers who could not be placed in Alsace were often stationed in arms and munitions factories elsewhere in Germany, where they were separated from their families, often shunned by the local population, and provided with substandard food and housing, a state of affairs which German professor Werner Wittich, reflecting once more the conflation of the economic and sexual subordination of working women, denounced as "a sort of white slavery."70

Once the war was over, many industrial employers who had hired female workers for wartime production released them to open up job possibilities for the returning soldiers, a policy supported by French government officials as well as socialist leaders such as Strasbourg's mayor Jacques Peirotes. ${ }^{71}$ If there was any protest from working women against this restoration of patriarchal order, it was not recorded in the records of the departmental administration or the socialist party press. The de-feminization of sectors such as heavy industry, transportation, and public works did not by any means, however, signify a return of Alsatian women from the factory to the home; as of 1926, women constituted the majority of the textile workforce in both Rhine departments and made up sizable minorities in other sectors, such as food processing, paper and printing industries, and the emerging service sector. ${ }^{72}$

While industry generally prospered in Alsace during the 1920 s, inflation devoured many of the gains, forcing workers into a series of usually unsuccessful strikes to defend their eroding economic position. ${ }^{73}$ Inflation affected working men and women both as producers on the job, and also as consumers in the domestic sphere, as it became increasingly difficult for working-class wives and mothers to provision their families with the necessities of life. This situation, closely analogous to the wartime inflation which provoked radical "female consciousness" among the women of Barcelona studied by Temma Kaplan, ${ }^{74}$ had the long-term consequence of drawing increasing numbers of women into the working class organizations which had traditionally kept them at a distance. While the organization of proletarian women as wage earners was still in its early stages at the start of the twentieth century, working class women had long been active in social protest as consumers, as countless reports of Old Regime bread riots attest. In 1919 the wives of striking ironworkers at the Dietrich forges in the northern Bas-Rhin responded indignantly to suggestions by the factory manager that their economic woes were due not to inflation but to wasteful spending on luxuries such as chocolate. ${ }^{75}$ During the twenties, however, and even more so during the years of the Depression, few working men and women dared to protest their conditions, given the danger of summary dismissal and the failure with which the (mostly defensive) strikes of the period was usually met. They would have their moment in the sun, and the opportunity for the assertion of their interests, during the short but pivotal period of the Popular Front. 
The Popular Front coalition, which was swept into power by national elections in the spring of 1936, fared poorly in Alsace, but the strike wave which followed the Left's electoral triumph resonated powerfully in the Rhine departments, as Alsatian workers clamoured to obtain their fair share of the popular triumph. In addition to purely economic grievances, the strike wave of June and July 1936 provided an opportunity for self-assertion among Alsatian workers. As if a veil had been lifted, male and female workers who had previously felt compelled to remain silent were able to voice their concerns and to express their pride and dignity as workers and also, not coincidentally, as family men and women. Workers at Spiertz et Cie in Strasbourg-Meinau thanked their comrades in other factories for supporting their July 1936 strike, proclaiming, "May the gentlemen entrepreneurs recognize for once that we too are men!" 76 Rural textile workers at Amos et Cie in Wasselonne joined the strike movement because they had been required to work ten to twelve hour days at meager piece rates, and noted that before the Popular Front, the threat of dismissal had kept them from protesting their lot, teporting that "often family fathers, in order to have bread for their children, had to swallow all of this with patience." 77 The experience of poverty had shaken the sense of masculinity of these workers, preventing them from playing the normative role of family breadwinner, and now that the political landscape had shifted in their favour, they rejoiced to affirm themselves as workers, as fathers, and as free men.

The female factory workers of Alsace, almost always among the most exploited labourers of the province, also made reference to normative gender roles in pressing their economic demands during the strike wave of 1936, focusing attention on how their low wages and demanding work schedule impeded the performance of their domestic duties. Women workers at the Gance et Cie basketmaking establishment in Drusenheim were faced with an employer lockout when their demands for $25 \%$ wage increases were refused. In addition to long hours on the job, the Freie Presse reported that, to earn a decent wage, "women were compelled to take work home with them, where family members had to assist them in their tasks." ${ }^{78}$ Such employer practices, it was observed, made a mockery of patronal homilies on the need to strengthen working class families. Female textile workers at Schaeffer et Cie, locked in a stalemate with their employer over wage demands, marched with their children to the subprefecture to demonstrate the reason why they needed to be paid more, and urged the subprefect to mediate their dispute. The ploy worked, and the women received a $14 \%$ pay increase and bonuses ranging from ten to twenty-five centimes per hour. ${ }^{79}$ Similarly, Henriette Heusch, who organized a union among the formerly nonunionized female textile workers of Wittenheim during the strike wave of 1936, declared to a CGT assembly that "women also want to work and struggle for a higher wage which would allow them to dress and feed their children properly." 80 These examples demonstrate that the normative role of women as mothers did not merely serve the conservative cult of domesticity, but 


\section{Left History 7.2}

also generated "female consciousness" which allowed women to present their demands more forcefully, as the mothers of needy children, in terms which the bourgeoisie could scarcely deny.

The Popular Front era thus marked a coming of age of sorts for Alsatian workers, who were able to speak their minds as free men and women to a greater degree than ever before, and who won unprecedented wage increases through participation in a strike movement which was itself unprecedented in the province for its near-universal scope, its political awareness, and its use of new tactics such as factory occupations. In retrospect, however, the Popular Front era also represents a high water mark, not to be repeated, and a moment of transition from one form of industrial society to another. The textile industry, the leading employer of women in Alsace, began to decline in absolute terms in 1926, and would not recover in the postwar period. The age of private industrial paternalism, a defining feature of nineteenth-century Alsatian society, came to an end, as most Alsatian firms incorporated in the early twentieth century, later to be joined by French and multinational corporate giants who established factories in the province, changes which replaced the personalized (if often hostile) labour relations with more anonymous dealings between corporations and union federations under the auspices of an expanding welfare state. The assumption by the state of unemployment insurance, family allowances, and other matters once in the hands of private employers, and the general abandonment of official efforts to "moralize" the working class also indicate a sea change in labour relations in the years after the Popular Front. ${ }^{81}$ Mass immigration, deindustrialisation, and the gradual disappearance of Alsatian dialect in the years since 1945 have also dealt major blows to Alsatian exceptionalism, as the province today resembles the rest of France much more than it did during the years covered in this study.

This paper has sought to demonstrate both the pervasiveness of the normative gender roles of the male breadwinner and the female nurturer in nineteenth and early twentieth century Alsace, and also the remarkable elasticity of these concepts, which could be used either to reinforce or to challenge the capitalist industrial order. Moral economists and social Catholics invoked the traditional patriarchal family as a model for a well ordered society based on deference and subordination. The working men and women of Alsace, products of that society and of the hegemony of patriarchal values, did not challenge the assumptions of what men and women ought to do, but the disparity between the bourgeois domestic ideal and their own socioeconomic condition, which prevented them from achieving that ideal, led them not to accept existing patterns of social relations, but rather to rebel against them. Their recognition of the hollowness of patronal claims to defend working-class family life led these workers to band together, and eventually to join powerful socialist and syndical organizations, in order to fight for the higher wages and shorter work hours that would allow them fully to realize themselves as husbands and wives, mothers and fathers, and ultimately as human beings. 
${ }^{1}$ Louis Villermé, Tableau de l'état physique et moral des ouvriers employés dans les manufactures de coton, de laine, et de soie (Paris 1840), Vol. II, 351, 355.

${ }^{2}$ For an analysis of different national patterns of working class formation in France and Germany, see the essays in Ira Katznelson \& Aristide Zolberg, eds., Working Class Formation: Nineteenth Century Patterns in Western Europe and the United States (Princeton 1986).

${ }^{3}$ Joan W. Scott, Gender and the Politics of History (New York 1988).

${ }^{4}$ Rachel Fuchs, Poor and Pregnant in Paris: Strategies for Survival in the Nineteenth Century (New Brunswick, N.J. 1992), 36.

${ }^{5}$ Katherine A. Lynch, Family, Class, and Ideology in Early Industrial France: Social Policy and the Working Class Family, 1825-1848 (Madison 1988); Elinor Accampo, Industrialisation, Family Life, and Class Relations: Saint Chamond, 1815-1914 (Berkeley 1989); Susan Pedersen, Family, Dependence, and the Origins of the Welfare State: Britain and France, 1914-1945 (New York 1993).

${ }^{6}$ Kathleen Canning, Languages of Labour and Gender: Female Factory Work in Germany, 1850-1914 (Ithaca 1996), 86.

${ }^{7}$ Mary Lynn Stewart, "Setting the Standards: Labour and Family Reformers" in Elinor Accampo, et. al., Gender and the Politics of Social Reform in France, 1871-1914 (Baltimore 1995), 127.

${ }^{8}$ For a description of the tasks involved in nineteenth century textile production and the gendered division of labour among them, see Villermé, Vol. 1, 3-12.

${ }^{9}$ Villermé, Vol. I, 37-41.

${ }^{10} \mathrm{Scott}, 143-6$.

${ }^{11} 1844$ figures taken from Marie Madeleine Kahan-Rabecq, La classe ouvrière en Alsace pendant la Monarchie de Juillet (Paris 1939), 146-7. Figures for 1899 taken from Statistisches Handbuch für Elsaß-Lothringen (1902), 250-1.

${ }^{12}$ Lynch, 3; Fuchs, 38-39.

${ }^{13}$ Lynch, 235.

${ }^{14}$ For a general overview of industrialisation and class relations in Alsace, see KahanRabecq, op. cit, Michel Hau, L'Industrialisation de l'Alsace, 1803-1939 (Strasbourg 1987), as well as my book, David Allen Harvey, Constructing Class and Nationality in Alsace, 1830-1945 (De Kalb, Il. 2001).

${ }^{15}$ Accampo, op. cit ., especially chapter 5 .

${ }^{16}$ Archives Départementales du Bas-Rhin, Strasbourg (hereafter: ADBR) AL 87 (483).

${ }^{17}$ Archives Départementales du Haut-Rhin, Colmar (hereafter: ADHR) $10 \mathrm{M} 11$.

${ }^{18} \mathrm{~L}$. Goguel, "Du progrès moral dạns les classes industrielles: rapport présenté à la Conférence pastorale de Strasbourg, le 17 juin 1858," booklet preserved in ADHR $10 \mathrm{M}$ 11.

${ }^{19}$ Kahan-Rabecq, 155.

${ }^{20}$ Villermé, Vol. I, 33-4.

${ }^{21}$ Fuchs, 102.

${ }^{22}$ Katherine A. Lynch, "Marriage Age among French Factory Workers: An Alsatian Example," Journal of Interdisciplinary History 16:3 (1986), 421.

${ }^{23}$ Heinrich Cetty, La famille ouvrière en Alsace (Rixheim 1883), 14.

${ }^{24}$ Cetty, 95-9, 139, 204.

${ }^{25}$ Kahan-Rabecq, 299. 
${ }^{26}$ ADHR $10 \mathrm{M} 8$.

${ }^{27}$ ADHR $10 \mathrm{M} 9$.

${ }^{28}$ Kahan-Rabecq, 8.

${ }^{29}$ Heinrich Herkner, Die oberelsässische Baumwollindustrie und ihre Arbeiter (Strasbourg 1887), 131.

${ }^{30}$ ADBR AL 27 (168).

${ }^{31}$ Jean-Marc Biry, Industrialisation en milieu rural: Le logement des ouvriers de l'entreprise De Dietrich (University of Strasbourg Thesis, 1981), 123.

${ }^{32}$ Roger Dufraise, "Le liberalisme social d'un maitre de forges alsacien" L'Actualité de l'Histoire 15 (April 1956), 7.

${ }^{33}$ Wage data from De Dietrich et Cie taken from Gaby Aron-Castaing, "Une grande entreprise en milieu rural: De Dietrich au XIXe siècle," Saisons d'Alsace 91 (1986), 102. Statistics on wages in the textile industry and the artisanal trades are taken from data collected by prefectoral surveys and recorded in the archives of the Rhine departments, notably in ADBR $10 \mathrm{M} 46$ and $13 \mathrm{M} 58$, and also in ADHR $10 \mathrm{M} \mathrm{8,1} \mathrm{Z} \mathrm{497,} \mathrm{and} 1 \mathrm{Z} 506$. The family budget estimate is taken from Villermé, Vol. I, 45.

${ }^{34}$ ADHR $10 \mathrm{M} 9$.

${ }^{35}$ Jean Quaetert, "The Politics of Rural Industrialization: Class, Gender, and Collective Protest in the Saxon Oberlausitz of the Late Nineteenth Century," Central European History 20 (1987), 108.

${ }^{36}$ Sandrine Kot, Des philanthropes aux politiques sociales: Solutions françaises et allemandes à la question sociale en Haute-Alsace (1850-1914) (University of Paris VII Dissertation, 1991), 201.

${ }^{37}$ Kot, 196-7.

${ }^{38}$ lbid, 228.

${ }^{39}$ Cercle Mulhousien, Association Populaire (Cercle Ouvrier). Fondation de M. Jules Siegfried à Mulhouse en 1868 sous le patronage de la Société Industrielle de Mulhouse (Mulhouse, 1886), 3, 22.

${ }^{40}$ Cetty, 217.

${ }^{41}$ Francis Hordern, L'Evolution de la condition individuelle et collective des travailleurs en Alsace au XIXe siècle (1800-1870) (University of Paris Dissertation, 1970), 421.

${ }^{42} \mathrm{~A}$ series of annual reports of the Colmarer Versorgungshaus is filed in ADBR AL 27 (459).

${ }^{43}$ For statements by the aforenamed scholars to this effect, see Sonya O. Rose, "Gender at Work: Sex, Class, and Industrial Capitalism" History Workshop Journal 21 (1986), 124; and Barbara Taylor, Eve and the New Jerusalem: Socialism and Feminism in the Nineteenth Century (New York 1983), 112.

${ }^{44}$ August Bebel, tr. Daniel De Leon, Woman under Socialism (New York 1904), 103.

${ }^{45}$ Temma Kaplan, "Female Consciousness and Collective Action: The Case of Barcelona, 1910-1918," in Nannerl Keohane, Michelle Rosaldo, \& Barbara Gelpi, eds, Feminist Theory: A Critique of Ideology (Chicago 1981), 55. The role of the proletarian woman as the "domestic minister of finance" is recorded in Villermé, Vol. II, 65.

${ }^{46}$ Wally Seccombe, "Patriarchy Stabilized: The Construction of the Male Breadwinning Wage Norm in Nineteenth Century Britain," Social History 11 (1986), 55.

${ }^{47}$ Joy Parr, The Gender of Breadwinners: Women, Men, and Change in Two Industrial Towns, 1880-1950 (Toronto 1990), 188, 198-9.

${ }^{48}$ ADHR 10 M 9. 
${ }^{49}$ ADHR $10 \mathrm{M} 9$.

${ }^{50} \mathrm{ADHR} 10 \mathrm{M} 9$.

${ }^{51}$ ADHR $10 \mathrm{M} 9$.

${ }^{52}$ ADBR 3 M 408.

${ }^{53}$ Villermé, Vol. I, 46.

${ }^{54}$ ADHR $10 \mathrm{M} 8$.

${ }^{55}$ Scott, 143.

${ }^{56}$ On this topic, see Herkner, 28, as well as Cetty, 140-3.

${ }^{57}$ ADHR $10 \mathrm{M} 9$.

${ }^{58}$ For the transition from French to German rule and its consequences for Alsatian workers, see Harvey, op.cit. , especially chapters 2 and 3 .

${ }^{59}$ ADBR AL 27 (168).

${ }^{60}$ Bebel, 3, 104.

${ }^{61}$ Ibid, 180, 187, 231, 224.

${ }^{62} 1$ May, 1898 brochure, in ADBR AL 27 (226).

${ }^{63}$ ADBR AL 27 (226).

${ }^{64} \mathrm{Kot}, 382-3$.

${ }^{65}$ Mary Nolan, Social Democracy and Society: Working Class Radicalism in Düsseldorf, 1890 1920 (Cambridge 1981), 123; Jürgen Kocka, Klassengesellschaft im Krieg: Deutsche Sozialgeschichte, 1914-1918 (Göttingen 1978), 56; SPD Elsaß-Lothringen Landesversammlung 16-17 Juli 1910(Strasbourg 1910), 15.

${ }^{66}$ ADHR $10 \mathrm{M} 9$.

${ }^{67}$ ADBR AL 87 (4372).

${ }^{68}$ For statements to this effect from employers in heavy industry, see ADBR AL 87 (314). ${ }^{69}$ Statistics on employment in major industrial establishments compiled in ADBR AL $121(1467),(1468)$.

${ }^{70}$ Quoted in Christian Baechler, L'Alsace entre la guerre et la paix: Recherches sur l'opinion publique, 1917-1918 (University of Strasbourg Dissertation, 1969), 146.

${ }^{71}$ Peirotes suggested replacing female with male labour in a January 20, 1919 letter to the military administration of the Bas-Rhin, preserved in ADBR AL 121 (1464).

${ }^{72}$ Annuaire Statistique (Bas-Rhin, Haut-Rhin, Moselle) Premier Volume: 1919-1931 (Strasbourg 1932), 238-244.

${ }^{73}$ Inflation indexes for the period can be found in Ibid., 301 .

${ }^{74}$ See Kaplan, op. cit.

${ }^{75}$ ADBR AL 121 (877).

${ }^{76}$ Die Freie Presse (official newspaper of the SFIO in the Bas-Rhin), July 15, 1936.

${ }^{77}$ Ibid, June 27, 1936.

${ }^{78}$ Ibid, July 8, 1936.

${ }^{79}$ Der Republikaner (official newspaper of the SFIO in the Haut-Rhin), June 20, 1936.

${ }^{80}$ ADBR AL 98 (696).

${ }^{81}$ On the rise of the welfare state in France and its impact on labour relations, see Richard Kuisel, Capitalism and the State in Modern France (Cambridge 1981), and Peter Köhler, et. al, The Evolution of Social Insurance, 1881-1981 (New York 1982). Subsequent scholarship has argued that gender was key to the ways in which social policies were envisioned and implemented in France; for example, Pedersen, op. cit., as well as the essays in Elinor Accampo, et. al., eds., Gender and the Politics of Social Reform in France, 1870-1914 (Baltimore 1995). 